\title{
Bacteriological Quality and Antibiogram of Isolates from Potable Water Sources in Ekosodin Community, Benin City, Nigeria
}

\author{
*EKHOSUEHI, A; AKHARAME, MO; OBAYUWANA, P
}

\author{
Department of Environmental Management \& toxicology, Faculty of life science, \\ University of Benin, Benin City, Nigeria. \\ *Corresponding Author's Email Address: amen.ekhosuehi@uniben.edu, +2348030649495
}

\begin{abstract}
This study sought to determine the bacteriological quality of some boreholes and storage tanks used for drinking and other domestic purposes in Ekosodin community and evaluated the antimicrobial susceptibility patterns of the groundwater resources isolates. A total of 48 samples were collected from three boreholes and storage tanks for a period of two months. Samples were analyzedfor microbiological content following standard procedures. Feacal Coliform (FC) and Feacal Streptoccocci (FS) counts and antimicrobial susceptibility patterns were evaluated using the Most Probable Number and Kirby-Bauer methods respectively. The mean FC counts $(1.2 \pm 0.3 \mathrm{Cfu} / 100 \mathrm{ml}-$ $55 \pm 10 \mathrm{Cfu} / 100 \mathrm{ml})$ and meanSF counts $(0 \mathrm{cfu} / 100 \mathrm{ml}-9.25 \pm 1.1 \mathrm{Cfu} / 100 \mathrm{ml})$ in some of the samples examined, exceeded the WHO limit of $0 \mathrm{Cfu} / 100 \mathrm{ml}$ for drinking water. Significant differences were recorded for mean FS counts betweensome boreholes and storage tanks. Escherichia coli (34\%), Klebsiella sp (23\%), Pseudomonas sp (19\%) and Feacal Streptococci $(12 \%)$ were amongst the identified isolates from the water samples. The antibiogram analysis revealed that all isolates (87\%) except some strains of Feacal Streptococci were sensitive to ciprofloxacin and $73 \%$ of isolates were resistant to Erythromycin. All isolates exhibited a multi drug resistance to at least eight antibiotics. The microbial analysis revealed a faecal contamination of the groundwater, making it unfit for drinking without proper disinfection.
\end{abstract}

\section{DOI: https://dx.doi.org/10.4314/jasem.v22i1.24}

Copyright: Copyright (C) 2018 Ekhosuehi et al. This is an open access article distributed under the Creative Commons Attribution License (CCL), which permits unrestricted use, distribution, and reproduction in any medium, provided the original work is properly cited

Dates: Received 15 December 2017; received in revised form 17 December 2017; accepted 27 December 2017

Keywords: Ciprofloxacin, Multidrug resistance, Feacal Coliforms, Feacal Streptococci, Erythromycin

In Nigeria, the inability of the Government to provide pipe borne water has led to the exploitation of groundwater for water supply by citizens. Groundwater is generally regarded as one of the pristine sources of water. However, recent studies have shown that the quality of groundwater in most urban areas in Nigeria is deteriorating fast (Ocheri et al., 2014).The contamination of groundwater quality has been related to location and construction of wells, proximity of wells to domestic waste dumpsites, abattoir, sanitary systems such as pit-latrines and septic tanks. Moreover, groundwater quality has been shown to vary seasonally. (Ocheri et al., 2014).

Pathogenic bacteria such as Escherichia coli, Aerobacter aerogenes, Klebsiella sp., Pseudomonas sp., Proteus sp., Staphylococcus sp. and Acaligenes sp. have been isolated from groundwater (Efuntoye and Apanpa, 2010 ; Onuoha, 2015). Some of these isolates, such as Pseudomonas aeruginosa and Klebsiella sp. can cause nosocomial infections in immunocomprised patients. (WHO, 2011).

Recent studies shows the proliferation of emerging contaminants such as antibiotic resistance genes and microbes in the environment (Berendonk et al., 2015). The unappealing manifestation of this situation is the increasing persistence of bacterial infections amongst the public (Frieri et al., 2016). This development is of public health concern and needs appropriate attention. Earlier studies on antimicrobial resistance focused more on environments and samples considered to be antibiotic resistance hotspots which includes; sewage, dairy effluent, municipal wastewater, medical environments and effluents (Harwood et al., 2001; Li et al., 2001; Brown et al., 2006) but only few extensive studies exist on the prevalence of antibiotic resistance in borehole water samples from solely residentially environments (Dwyer et al.,2017). Hence this study set out to research on the antimicrobial susceptibility pattern of groundwater isolates from Ekosodin community which is majorly inhabited by students and local inhabitants. Therefore the objective of this study was to assess the bacteriological quality of the groundwater sources in Ekosodin community and determine the antibiogram of the isolates from the assessed groundwater samples.

\section{MATERIALS AND METHODS}

Study area: The study was conducted in Ekosodin community; a town located in Ovia North East Local Government Area of Edo state in Nigeria. Ekosodin is mostly populated by students who live outside the school residence hostels of University of Benin and the major source of water for drinking and other domestic purposes is boreholes. Three sampling sites were selected which were A $\left(06^{\circ} 24^{\prime} 28.2^{\prime \prime} \mathbf{N}, 005^{\circ} 37^{\prime}\right.$ 


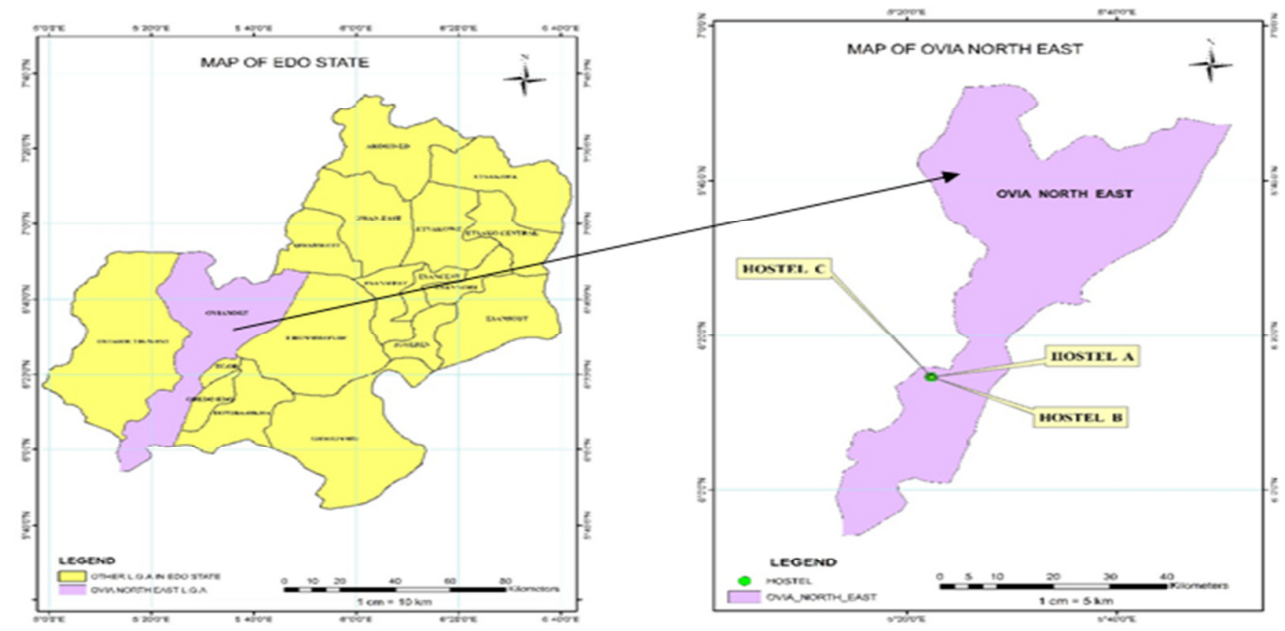

Fig 1. Map of study area

Sample collection: A total of 48 water samples were obtained from three boreholes and their respective storage tanks at an interval of two weeks from May to June. $250 \mathrm{ml}$ capacity sterile bottles were pre-sterilized in an autoclave at $121^{\circ} \mathrm{C}$ for 15 minutes before they were used for collecting water samples. After allowing several litres of water to run for 5 minutes as waste, water samples were obtained by allowing water to flow aseptically from the dispensing tap into the glass bottles. The bottles were then corked and transported to the laboratories for microbial analysis.

Multiple tube technique: $50 \mathrm{~mL}, 10 \mathrm{~mL}$ and $1 \mathrm{~mL}$ each of the water samples were transferred into prepared MacConkey broth and Azide dextrose broth at $50 \mathrm{~mL}$ (double strength), $10 \mathrm{~mL}$ (double strength) and $5 \mathrm{~mL}$ (single strength) for the enumeration of Feacal coliform and Feacal Streptococci respectively. The bottles were then transferred to an incubator and left there for 48hours. Bottles containing MacConkey broth were observed for a colour change while bottles with Azide dextrose broth were observed for turbidity. Positive results that contained coliforms changed from pink to yellow while positive bottles for azide broth were turbid suggesting the presence of Feacal Streptococci. Thereafter, the positive results from MacConkey broth were sub-cultured into Eosin Methylene Blue agar (EMB) to produce discrete colonies of total coliform and to isolate feacal coliform respectively. The positive results from the Azide dextrose broth were sub-cultured into MacConkey agar. All petri-dishes were incubated for 24hours. Colonial characteristics and morphological analysis were carried out on those agar plates (modified Efuntoye and Apanpa, 2002).

Antibiotic Susceptibility Test: A 0.5McFarland standard solution of the test organism was prepared by inoculating the organism in normal saline solution.
From this solution, the organism was streaked on a Mueller-Hinton agar plate using a cotton swab while ensuring that the entire surface of the agar was streaked. Using a pair of sterile forceps, the antibiotic disc which included; Pefloxacin $(10 \mu \mathrm{g})$, Gentamycin

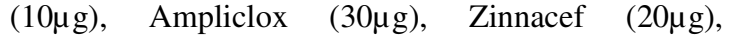
Rocephin $(30 \mu \mathrm{g})$, Amoxicillin $(30 \mu \mathrm{g})$ Ciprofloxacin $(10 \mu \mathrm{g})$, Streptomycin $(30 \mu \mathrm{g})$, Septrin $(30 \mu \mathrm{g})$ and Erythtomycin $(19 \mu \mathrm{g})$ was placed on the inoculated agar and the plate was incubated at $37^{\circ} \mathrm{C}$ for 24 hours. The zones of inhibition of each antibioticwere measured in millimeters. (NCCLS,2000).

Statistical and Data Analysis: The differences between Feacal coliform and Feacal Streptococci countsin both boreholes and storage tanks were analyzed using Generalized Linear Model (GLM, ANOVA).Significance levels were determined at a confidence interval of $95 \% \quad(\mathrm{P}<0.05)$; where the overall statistics were significant, a Tukey's Honestly Significant difference (HSD) post hoc test was used to separate the means. All analysis were performed using SPSS statistical package (SPSS version 16.0, Chicago, IL, USA).

\section{RESULTS AND DISCUSSION}

The mean FC counts obtained in this study ranged from $1.2 \pm 0.3 \mathrm{cfu} / 100 \mathrm{ml}-55 \pm 10 \mathrm{cfu} / 100 \mathrm{ml}$ while mean FS counts ranged from $0 \mathrm{cfu} / 100 \mathrm{ml}-$ $9.25 \pm 1.1 \mathrm{cfu} / 100 \mathrm{ml}$, (Figures 2 and 3 ). The FC and FS counts in some samples exceeded the World Health Organisation (WHO) guideline value of $0 \mathrm{cfu} / 100 \mathrm{ml}$ for drinking water (WHO, 1997). FC results obtained in this study corroborates results obtained from similar studies on the microbial quality of borehole and well water in Ijebu Ode and Ago-Iwoye communities in South Western Nigeria, which also reported a greater than $0 \mathrm{cfu} / 100 \mathrm{ml}$ in the samples examined (Olorunjuwon et al.,2013; Efuntoye and 
Apanpa, 2010). Meanwhile at $\left(\mathrm{P}=0.007, \mathrm{~F}_{1,23}=9.09\right)$ there was a significant difference in the mean counts of SF obtained between the two water sources (ie borehole and storage tanks) in two of the hostels. Generally, storage tanks had higher counts except in Hostel B. In hostel C for instance, there was no SF found in the borehole water but it had in it storage tanks a mean count of $8.25 \pm 1.7 \mathrm{cfu} / 100 \mathrm{ml}$ (see Fig.3).Since SF are not known to multiply in groundwater, the higher SF counts in the storage tanks can be attributed to the poor handling of stored water by the consumers (Sinton et al., 1993). Contamination could also have originated from the environment through dust particles transported into the tank. WHO report on protecting groundwater for health 2006, identifies leakage from sanitary systems such as septic tanks as the major source of feacal contamination of groundwater. Arguably, the distance between borehole and septic tank can influence the contamination of the groundwater by the septic tanks. Although, there have been reports to indicate a weak/negative correlation between the distance of a pit latrine and/or septic tanks and boreholes on the groundwater quality (Banda et al., 2014; Ahmed et al., 2002; Howard et al.,2003; Tandia et al., 1999), the distance between a borehole and septic tank remains an important factor in determining groundwater contamination. According to the WHO Fact sheet on septic tanks (see Fact sheets 3.9,http://www.who.int/water_sanitation_health/sanita tion-waste/fs3_9.pdf). The minimum acceptable distance between borehole and septic tanks should be $30 \mathrm{~m}$.From Table 1, selected Hostels did not meet the $30 \mathrm{~m}$ limit set by the WHO indicating that the observed feacal contamination in borehole water samples most likely originated from seepage from septic tanks in the study locations.

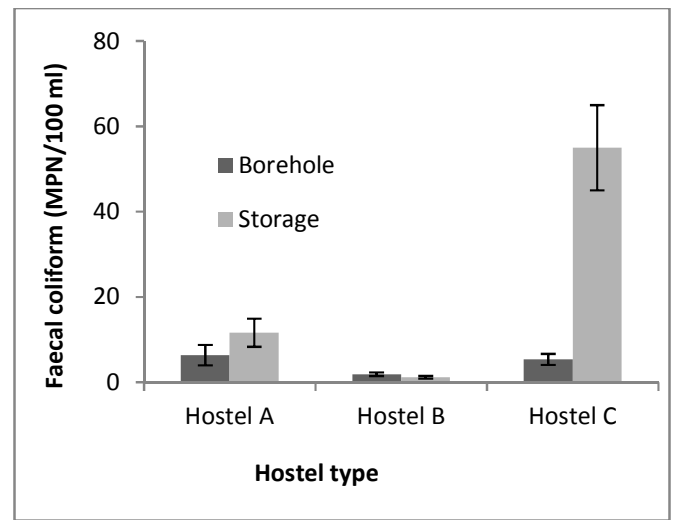

Fig2: Mean Feacal coliform counts in boreholes and storage tanks

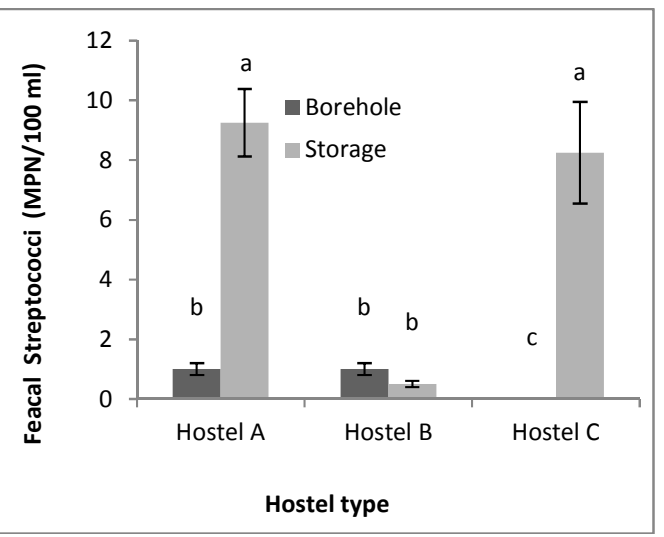

Fig3: Mean Feacal Streptococci counts in boreholes and storage tanks. Bars followed by different letters (a-c) indicates difference in means.

Table 1.The distance apart, distance of boreholes to septic tanks and elevations measurements of boreholes and storage tanks

\begin{tabular}{lllll}
\hline Location & Distance Apart & $\begin{array}{c}\text { Distance To } \\
\text { Septic Tanks }\end{array}$ & \multicolumn{2}{c}{ Elevations } \\
\hline & & & Well heads & Septic Tanks \\
\hline Location A & & 7.28Metres & 103 Metres & 108 Metres \\
Location B & 260.76 Metres & 10.44Metres & 112 Metres & 105 Metres \\
Location C & 351.74 Metres & 28.28Metres & 101 Metres & 108 Metres \\
\hline
\end{tabular}

Samples from both boreholes and storage tanks tested positive for the presence of 77 isolates including Escherichia coli (34\%), Klebsiella sp (23\%), Pseudomonas sp.(19\%), Proteus sp (5\%), Enterobacter sp (3\%) and Feacal Streptococci(12\%). With the exception of Escherichia coli, all other isolates are ubiquitous bacteria genera often isolated from soil-water-plant environments (Somaratne and Halla, 2015).Similar studies carried out in Ijebu- Ode and Ogbomoso communities also isolated Pseudomonas aeruginosa, Escherichia coli, Klebsiella sp, Enterobacter sp and Proteus sp from borehole water (Olorunjowon et al.,2012 and Lateef et al., 2012). Even though organisms isolated in this study are naturally found in the environment, they can pose health threats to individuals with suppressed immune systems (Ali et al., 2011).Severe health effects such as gastroenteritis and Heamolytic Uraemic Syndrome have been associated with consuming Escherichia coli
groundwater.(WHO, 2006).

Bacteria isolates were screened for their antimicrobial susceptibility pattern. The antibiogram test towards ten antibiotics including perfloxacin, gentamycin, ampicillin and ciprofloxacin (Figure 4) revealed that $73 \%$ of the isolates were resistant to erythromycin while all the isolates (87\%) except some species of Feacal Streptococci were completely sensitive to ciprofloxacin. Astoundingly, all isolates exhibited a multi drug resistance to at least eight of the antibiotics with Enterobacter sp. exhibiting the highest resistance to nine of the ten antibiotics it was exposed to. The findings from this study, suggests that the isolates may have acquired resistant genes to the tested antibiotics, probably due to exposure to sublethal doses in the environment or possession of intrinsic genes by the isolates. A couple of studies elucidate on the occurrence of antibiotics in trace amounts in the 
environments including domestic wastewaters and sewage systems e.g septic tanks which are viable sources where these isolates can possibly acquire resistant genes.(see Carlson and Yang, 2005; Sui et al., 2015).

Moreover, antimicrobial resistance of isolates from the Enterobacteriacea family where the isolates from the study belongs, is well documented (Arthur et al., 1987; Losch et al., 2008;Lynch et al., 2013).For instance, Enterobacter sp (especially E. cloacae and E.aerogenes) which are well-known opportunist pathogens causing nosocomial infections exhibits intrinsic resistance towards amoxicillin and thirdgeneration cephalosporins like rocephin,(Bosi et al.,1999; Mezzatesta et al., 2012, Pontron et al., 2013). This resistance is induced by the overexpression of the AmpC $\beta$-lactamases which are encoded on their chromosomes (Pontron et al., 2013). AmpC $\beta$-lactamases is also known to be transferred to organisms lacking or poorly expressing chromosomal AmpC genes such as Klebsiella pneumonia, Escherichia coli and Proteus mirabilis through transmissible plasmids (Jacoby, 2009). The resistance of Escherichia coli, Klebsiella sp and Proteus sp to erythromycin have also been documented (Arthur et al.,1987). Similarly, Ateba and Maribeng (2011) reported that $75 \%$ - $100 \%$ of Enterococcus species including Enterococcus feacalis (which is a Feacal Streptococci) from groundwater sources were resistant to erythromycin amongst other antibiotics.

In a similar trend, as observed in this study, the sensitivity of all isolates to ciprofloxacin was also reported by Mulamattathil et al., 2014. Results from their study, revealed that all environmental isolates which included Pseudomonas aeruginosa, Escherichia coli and Proteus vulgaris were completely sensitive to neomycin, streptomycin and ciprofloxacin. They also recorded the resistance of isolates to erythromycin, trimethoprim and amoxicillin. In another study by Onuoha (2015), Escherichia coli from well water sources exhibited sensitivity to ciprofloxacin and pefloxacin.

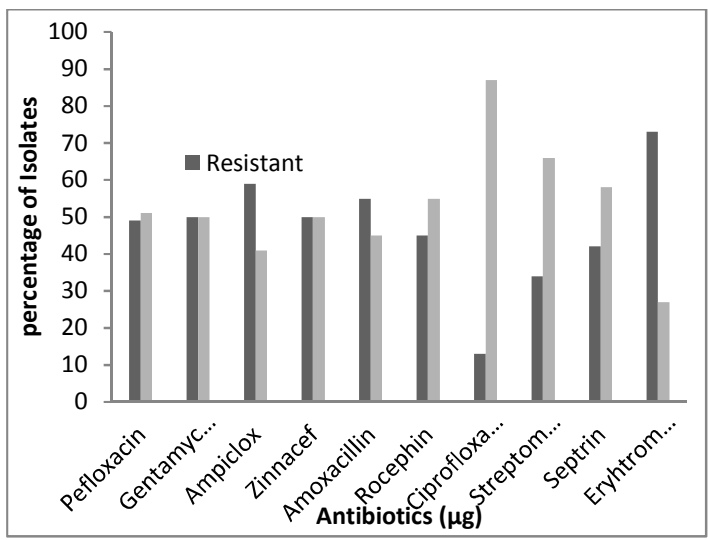

Fig4. Mean resistance and sensitivity percentages of isolates

Conclusion: This study confirms the presence of Feacal coliforms and Feacal Streptococci in the water samples examined. More worrisome, it revealed that isolates exhibited multi drug resistance to the antibiotics tested. Generally, findings from this research suggests a contamination of the groundwater sources and the occurrence of antibiotics resistant bacteria in Ekosodin. In view of the above fact, it is therefore recommended that the water from these boreholes be treated before drinking.

\section{REFERENCES}

Ahmed, KM; Khandkar, ZZ; Lawrence, AR; Macdonald, DMJ; Islam MS (2002). Appendix A: an investigation of the impact of on-site sanitation on the quality of groundwater supplies in two periurban areas of Dhaka, Bangladesh. In: Assessing Risk to Groundwater from On-site Sanitation: Scientific Review and Case Studies. Keyworth, UK:British Geological Survey, 37-67. Available: http://r4d.dfid.gov.uk/pdf/outputs/r68692.pdf

Ali, H; Bacha, K; Ketema, T (2011). Bacteriological Quality and Antimicrobial Susceptibility of Some Isolates of Well Waters Used for Drinking in Jimma Town, Southwest Ethiopia.Ethiop. J. Health Sci. 6: 95-108.

Arthur, M;Andremont, A;Courvalin, PC (1987). Distribution of Eryhtromycin Esterase and rRNAMethylase Genes in Members of the Family Enterobacteriacea Highly Resistant to Erythromycin.Antimicrob. AgentsChemother. 31: 404-409

Ateba, N;Maribeng, D (2011). Detection of Enterococcus Species in Groundwater from some rural communities in the Mmabatho area, South Africa: A Risk Analysis. Afr. J. Microbiol. Res. 5: 3930-3935.

Banda, J; Mbewe, R;Selestine, H;Halwindi, H (2014). Effect of Siting Boreholes and Septic Tanks on Groundwater Quality in St. Bonaventure Township of Lusaka District, Zambia.International Journal of Environmental Science and Toxicol.Research 2:191198.

Berendonk, TU ; Manaia, CM ; Merlin, C ; FattaKassino, D ; Ctryn, E ; Walsh, F ; Burgmann, H ; Sorum, $\mathrm{H}$; Nostrom, $\mathrm{M}$; Pons, $\mathrm{M}$; Kreuzinger, $\mathrm{N}$; Huovinen, P ; Stefani, S; Schwartz, T; Kisano, V; Baquero, F ; Martinez, JL (2015). Tackling Antibiotic Resistance: the Environmental Framework. Nat. Rev.Microbiol. 13: 310-317

Bosi, C; Davin-Regli,A; Bornet,C; Malléa,M; Pagès,JM; Bollet,C (1999). Most Enterobacteraerogenesstrains in France belong to a prevalent clone. J. Clin.Microbiol. 37: 213 X C652169.

Brown, KD; Kulis, J; Thomson, B ;Mawhinney, DB (2006). Occurrence of Antibiotics in Hospital, Residential and Dairy Effluent, Municipal Wastewater and Rio Grande in New Mexico.Sci. Total Environ. 366: 772-783 
Carlson, K ; Yang, S (2005). Simultaneous Extraction and Analysis of 11 Tetracycline and Sulfonamide Antibiotics in Influent and Effluent Domestic Wastewater by Solid- Phase Extraction and Liquid Chromatography- Electrospray Ionization Tandem Mass Spectrometry.J. Chromatogr.A 1097: 40-53

Dwyer, JO ;Hynds, PD; Adley, C ; Ryan, MP (2017). Evaluation of Levels of antibiotic Resistance in Groundwater Derived E. coli Isolates in the MidWest of Ireland and Elucidation of Potential Predictors of Resistance. Hydrogeol. J. 4: 939-951

Efuntoye, O; Apanpa, O (2010).Status of Contamination and Antibiotic Resistance of Bacteria from well water in Ago-Iwoye, Nigeria.J. Appl. Biosci.35: 2244-2250.

Frieri, M ; Kumar, K ; Bouhn, A (2017). Antibiotic Resistance.J. Infect. Public Health10: 369-378

Fact sheet 3.9. Septic Tanks Available: http://www.who.int/water_sanitation_health/sanitati on-waste/fs3_9.pdf (Accessed15th December, 2017)

Harwood, VJ; Brownell, M;Perusek, W; Whitlock, JE (2001). Vancomycin-Resistant Enterococcus spp. Isolated from Wastewater and Chicken Feces in the United States. Appl. Environ Microbiol. 10: 49304933

Howard, G; Pedley, S; Barrett, M; Nalubega, M; Johal, K. (2003). Risk factors contributing to microbiological contamination of shallow groundwater in Kampala, Uganda.Water Res. 37:3421-34

Jacoby, GA (2009).AmpC betalactamases.Clin.Microbiol. Rev. 2:161-182

Lateef, A ;Kolawole, L ; Agosu, O. (2012). Quality Assessment of Some Groundwater Samples in Ogbomoso Metropolis, Southwest Nigeria.Journal of Environment and Earth Science 2:39-47.

Li, X ; Atwill, ER ; Antaki, E ; Applegate, O ; Bergamaschi, B ; Bond RF ; Chase, J ; Ransom, KM ; Samuels, W ; Watanabe, N ; Harter, T (2015). Feacal Indicator and Pathogenic Bacteria and Their Antibiotic Resistance in Alluvial Groundwater of an Irrigated Agricultural Regions with Dairies. $J$. Environ. Qual. 44:1435-1447

Losch, LS ; Alonso, JM ; Merino, LA (2008). Occurrence of Antimicrobial Resistant Enetrobacteriacea in water from Different Sources in a Sub- Tropical Region of Argentina.AmbiAgua,Taubate 3: 28-36

Lynch, JP; Clark, NM; Zhanel, GG (2013). Evolution of antimicrobialresistance among Enterobacteriaceae (focus on extended spectrum blactamasesandcarbapenemases).Expert Opin. Pharmacother. 14: 199-210.

Mezzatesta,ML; Gona, F; Stefani, S (2012). Enterobacter cloacae complex: clinical impact and emerging antibiotic resistance.

FutureMicrobiol.7:887-902.

doi:

10.2217/fmb.12.61

Mulamattathil, GS; Bezuidehout, C;Mbewe, M;Ateba, CN (2014). Isolation of Environmental Bacteria from Surface and Drinking Water in Mafikeng, South Africa and Characterization Using Their Antibiotic Resistance Profiles.J.Pathog. 371208.Doi: 10.1155/2014/371208

NCCLS (2000). (National Committee for Clinical Laboratory Standards) National Committee for ClinicalLaboratoryStandards, Performance Standards for Antimicrobial Disk SusceptibilityTests,222 Approved Standard M2-A7, 7th Ed., National Committee for Clinical Laboratory Standards, Wayne, PA.

Ocheri, M; Odoma, L; Umar, N (2014). Groundwater Quality in Nigerian Urban Areas: A Review. Global J. Sci. Front. Res. 14: 35-46

Olorunjuwon, B; Adeleke, O;Temitope (2013). Microbial Quality and Antibiotic Susceptibility Profile of Bacterial Isolates from borehole Water Used by Some Schools in Ijebu-Ode, SouthWestern Nigeria. Scholars Acad. J.Biosci.1:4-13

Onuoha, C (2015). Antibiotics Susceptibility Pattern of Escherichia coli Isolated from Well Water in Afikpo, South Eastern Nigeria. AASCIT Journal of Biology 3:38-42.

Potron, A; Poirel, L; Rondinaud, E; Nordmann,P (2013).Intercontinental spread of OXA-48 $\beta$ lactamase-producing Enterobacteriaceae over a 11yearperiod, 2001 to 2011. Euro.Surveill. 18:20549. doi:10.2807/1560- 7917.ES2013.18.31.20549

Sinton, LW; Donnison, AM; Hastie, CM (1993). Feacal Streptococci as feacal pollution indicators: A review, Part 1 Taxonomy and enumeration.New Zeal.J.Mar. Fresh. 27:101-115

Somaratne, N; Halla, G (2015). Review of Risk status of Groundwater Supply Wells by Tracing the Source of Coliform Contamination. Water 7:3878-3905.

Sui, Q; Cao, X; Lu, S; Zhao, W; Qui, Z; Yu, G (2015). Occurrence, sources and fate of pharmaceuticals and personal care products in the groundwater: A review. Emerging Contaminant 1:14-24

Tandia, AA; Diop, ES; Gaye, CB (1999). Nitrate groundwater pollution in suburban areas: example of groundwater from Yeumbeul, Senegal. $J$ Afr. Earth Sci. 29:809-822.

World Health Organization (2011).Guidelines for drinking water quality. Fourth Edition, Geneva.

World Health Organization (1997).Guidelines for drinking water quality. Second Edition, Geneva

World Health Organization (2006). Protecting Groundwater for Health: Managing the Quality of Drinking Water Sources.IWAPublishing, London 